\title{
Effects of Noise and Control in Mine Operation
}

\section{Amosu C.O.}

Abstract: Noise and noise induced hearing loss (NIHL) in the workplace is a serious issue. Not only can it affect hearing, it can also affect ability to work safely. This is because noises make it each have a responsibility for safety in relation to noise. This paper informs underground and surface mine operators and mine workers to recognise, manage and control risks associated with occupational noise exposure. It explains the health effects of noise, source and noise exposure types; measurement of exposure standards and control measures that can reduce these risks.

Keywords: Noise, Effect, Mine, operation, Decibel, Source, Frequency, Barrier, Human, Health, Workers.

\section{INTRODUCTION}

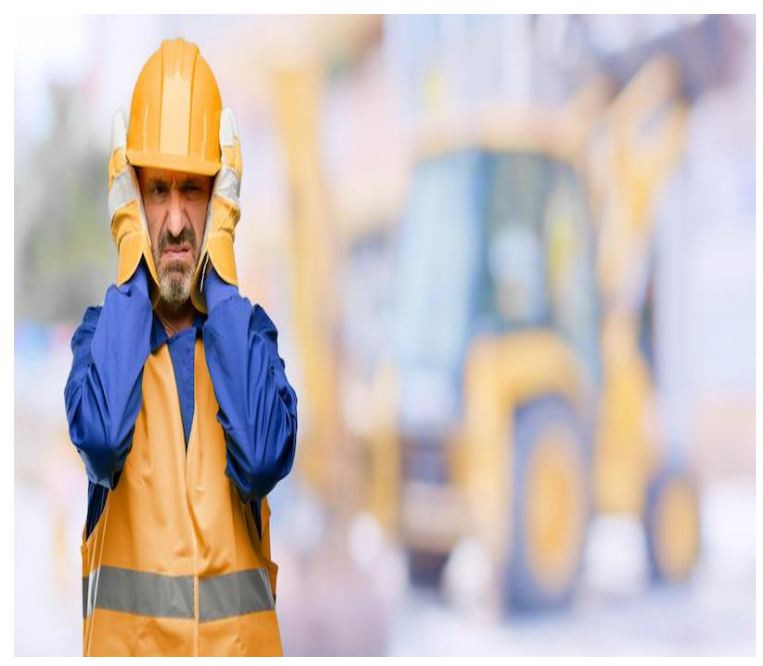

Figure 1: Effects of Noise (asmj.com.au)

Noise is an unwanted sound without acceptable relevance of music. In mining, noise is usually produced by heavy earthmoving environmental equipment. The sophistication of instrument changes as mining events and factors of the environment advances which also rely on their strategic position. The cumulative noise derived from mining and its equipment changes from its level and quality. In mining, majority of the mining machineries generates noise levels in the range of $85-120 \mathrm{~dB}(\mathrm{~A})$ of which prolonged exposures can lead to induced- noise hearing damage in mine workers and causing auditory health challenges. Hearing damage can disrupt the ability to communicate among miners. In summary, hearing loss or damage hinders the overall health of the man.

\footnotetext{
Manuscript received on 28 August 2021 | Revised Manuscript received on 07 September 2021 | Manuscript Accepted on 15 November 2021 | Manuscript published on 30 November 2021. * Correspondence Author

Amosu C.0.*, Department of Mineral and Petroleum Engineering Yaba College of Technology, Lagos, Nigeria. E-mail: muyixx1zillion@gmail.com, Cyril.amosu@yabatech.edu.ng

(c) The Authors. Published by Lattice Science Publication (LSP). This is an open access article under the CC-BY-NC-ND license (http://creativecommons.org/licenses/by-nc-nd/4.0/)
} difficult to hear instructions or safety warnings. Mine workers

Hearing loss $(\mathrm{HL})$ is the difference in decibel between the thresholds frequency of audibility of an affected person and the one who has a normal hearing at the same given frequency. In the minerals and mining industry, hearing loss or its damage is viewed as a critical challenge of health corroborated by different organizations of health such as USEPA - United States for Environmental Protection Agency; NIOSH - National Institute for Occupational Safety and Health; and the WHO - World Health Organisation. According to NIOSH, in 1976, mining of coal led to coal miners having health challenges that were worse than the average, nationally.

\section{SOME NOISE TERMINOLOGIES DECIBEL (DB)}

The decibel $(\mathrm{dB})$ is a ratio of two quantities with the same unit or a unit value of logarithmic measurement which expresses its size compared to an actual level of reference, i.e.

Decibel $=10 \log \left(\mathrm{P} / \mathrm{P}_{\text {ref }}\right)$

Where $\mathrm{P}=$ Signal power $(\mathrm{Watt}) ; \mathrm{P}_{\text {ref }}=$ Reference power (Watt) - usually between (10 - 12 Watt).

(ii) SOUND POWER LEVEL (SPL)

Sound power is the rate of sound energy or the energy of sound produced per unit time from a source of sound (Joules/seconds or Watt).

$\mathrm{L}_{\mathrm{w}}=10 \log \left(\mathrm{N} / \mathrm{N}_{\mathrm{o}}\right)$

Where $\mathrm{N}=$ sound power $(\mathrm{Watt})$

\section{SOUND INTENSITY LEVEL /ACOUSTIC}

Sound Intensity is Sound Power level (Watt) per unit area (Watt/Metre ${ }^{2}$.

$\mathrm{L}_{\mathrm{I}}=10 \log \left(\mathrm{I} / \mathrm{I}_{\mathrm{ref}}\right)$

Where $\mathrm{L}_{\mathrm{I}}=$ Sound Intensity Level $(\mathrm{dB}), \mathrm{I}=$ Sound Intensity (Watt/Metre ${ }^{2}$ );

$\mathrm{I}_{\text {ref }}=$ Reference Sound Intensity (Watt/Metre $\left.{ }^{2}\right)$ - usually between (10 - 12 Watt / Metre $\left.^{2}\right)$.

(iv) SOUND PRESSURE LEVEL

This is described as sound pressure being converted to the decibel scale. For instance $0 \mathrm{~dB}=0.00002 \mathrm{~Pa}$. Its unit is $\mathrm{N} / \mathrm{m}^{2}$ or Pa.

\section{(v) A-WEIGHTED DECIBELS}

A-Weighted Decibel is a one numbered noise level measure which combines sound levels at all frequencies and gives it as a scale conceived by the ear of man.

\section{NOISE METHODOLOGY}

Noise levels measurements are made in a-weighted decibels units in order to describe man's hearing to sound energy sources and his perception clearly and closely.

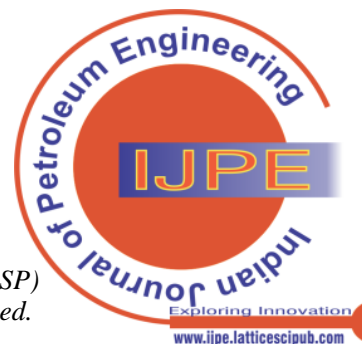




\section{Effects of Noise and Control in Mine Operation}

The A-weighted sounds are measured in unit of decibel, i.e. $\mathrm{dB}(\mathrm{A})$. It is difficult to conceive noise variation of less than three $\mathrm{dB}(\mathrm{A})$ from a highway source of undisrupted and uninterrupted noise, but a ten $\mathrm{dB}$ (A) noise will amplify sounds to the average hearer as though the noise has magnifies itself twice as loud. (Noise Impact Study, 2005).

Every day in the United States Noise-induced hearing loss (NIHL) has been the most usual occupational sickness with about 30 million workers critically exposed to extreme levels of noise [NIOSH 1996]. Of great concern is the mineral and mining sector which has extreme occurrence of terrible noise exposure and has earned the second position

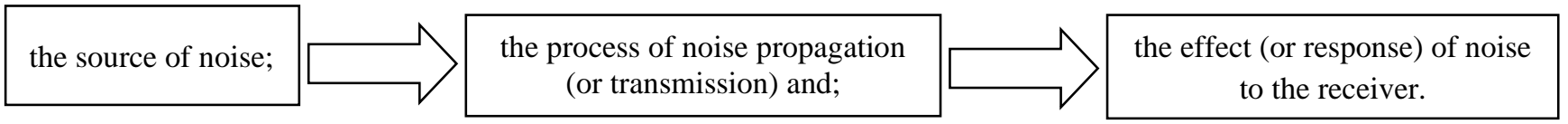

\section{Figure 2: Noise control}

The control of first-level noise affects engineering noise source and how to decrease and terminate them. The control of second-level noise affects flow of noise and how to manage it before it harms the receiver using standards, technologies, formulas, algorithms metrics, and other methods. Systems of noise sources such as equipment, machines, methods and processes must be well-comprehended in terms of their sources, transmission and response. If the control of first-level noise fails, then protection against noise is necessary (see figure 1). It shows a perspective of the first and second noise controls (Noise Impact Study, 2005).

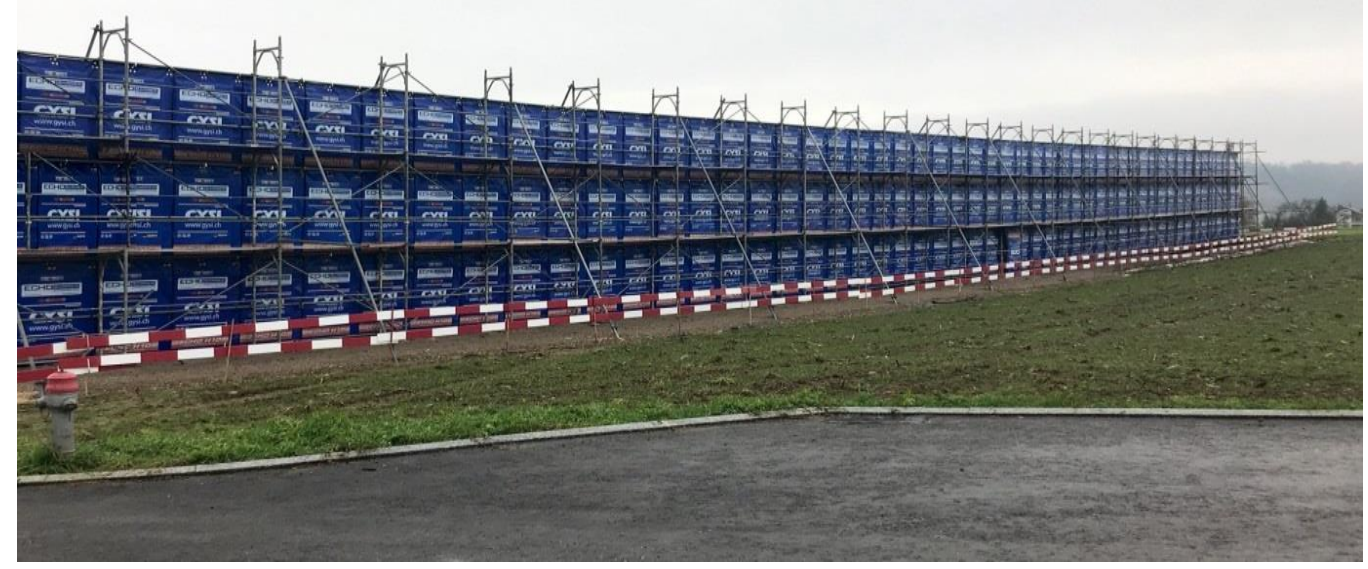

Figure 3: Mining Noise Control Management- Acoustic Barrier (blog.echobarrier.com)
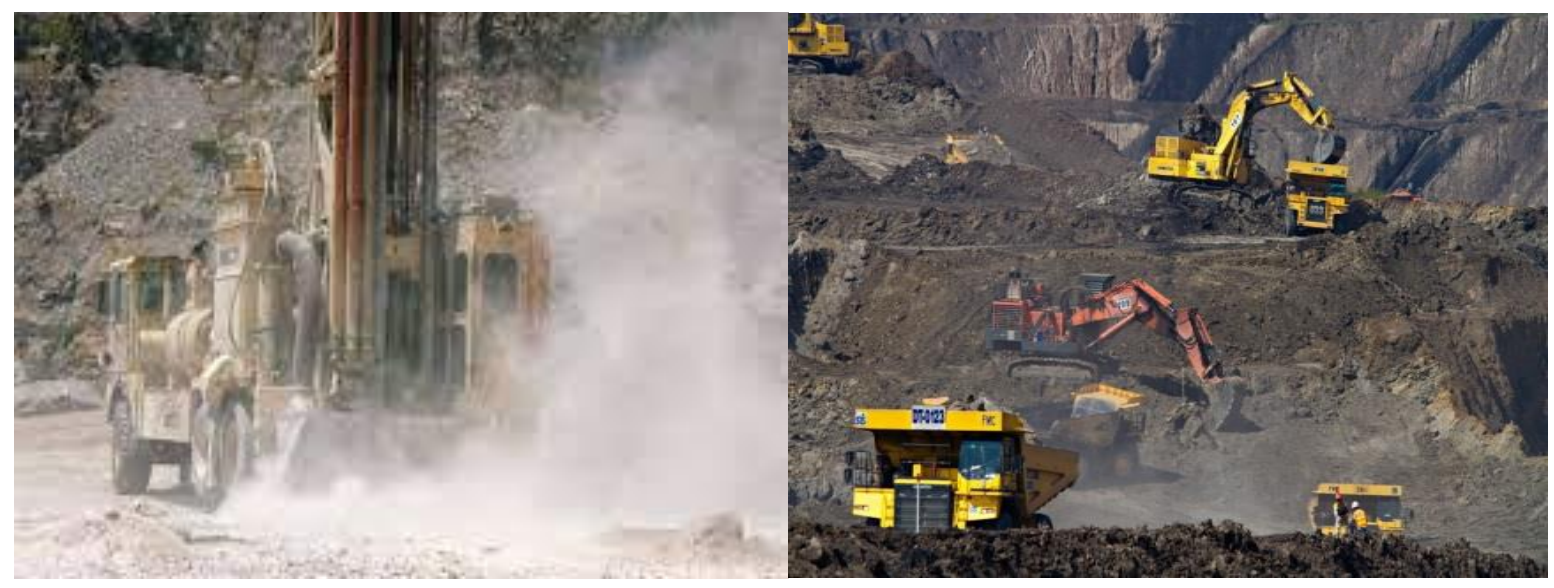

Figure 4: Dangerous Source of noise (stat.nj.us; blog.echobarrier.com)

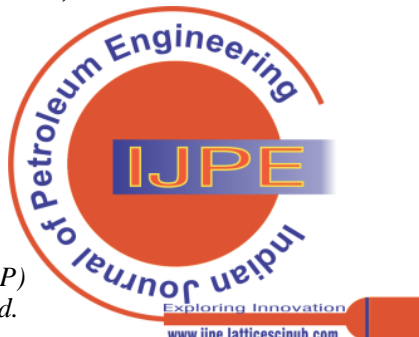




\section{THE SOURCES OF NOISE}

The physics of noise production relies on the integration of various system, its technological designs, equipment and operational process. Noise engineering is understood when each of these sources of noise are spotted out and particularly put under control. Examples of the sources of noise include internal combustion engines, vibrating components, electrical machineries, irregular fluid flow; impacts process operations, fans and so on.

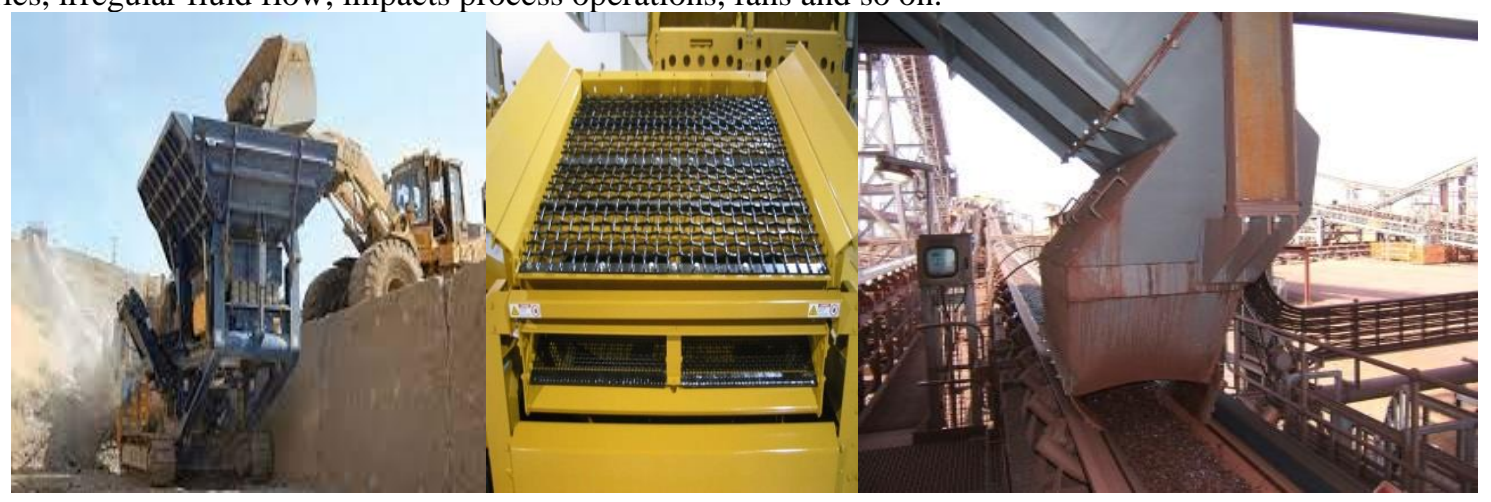

Figure 5: Crushers, Screen and Chutes (miningmagazine.com, minesep.com and im-mining.com)

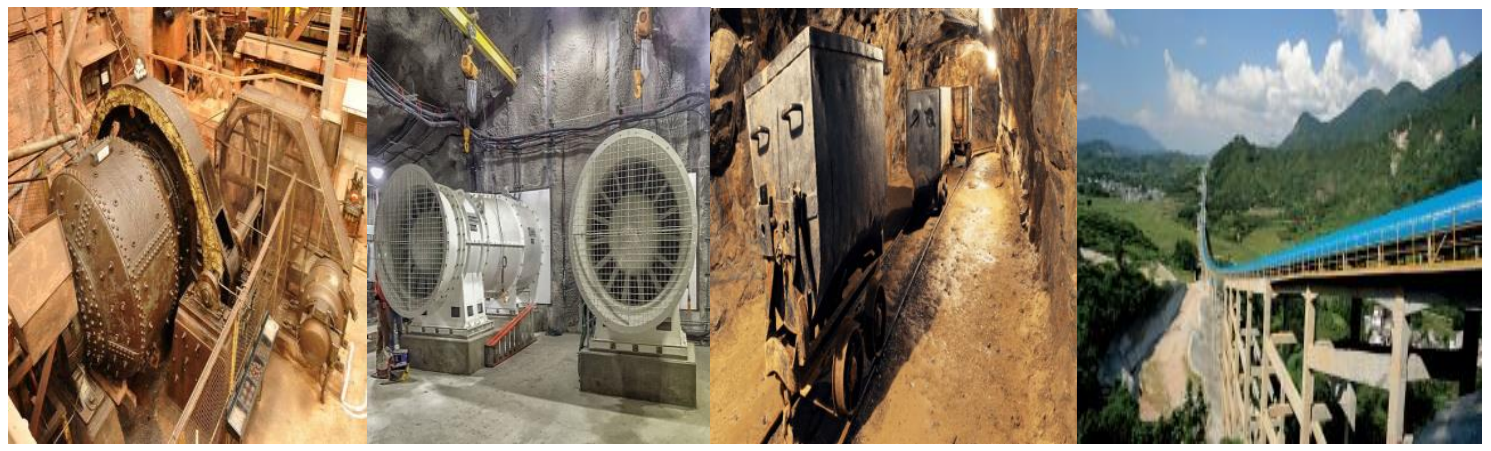

Figure 6: Milling, Fan in the mine, Ore train and Conveyor Belt (emrj.com, intl.siyavula.com, canadianminingjournal.com and spendrupfanco.com)

Other sources are drilling and blasting in mines; metal cutting and riveting; crushing and grinding; shake-out and screening. To reduce or terminate noise, the aim should be the sources, i.e. the point or location of mechanical energy, plate's vibration, turbulent flow of fluid, shocks and friction between solids, and misaligned rotating machines (Rigard, 2018).

\section{HIERARCHY OF NOISE CONTROL AMONG WORKERS}

Three methods to reduce worker noise exposure are:

1. Position engineering noise controls apparatus to decrease and terminate noise at the source before interface with mine workers.

2. Using administrative noise controls to restrict the number of exposures of workers to noisy locations.

3. Wearing personal protective equipment (PPE) for hearing protection,

The application of engineering noise controls is the best alternative because it addresses noise directly from source. Using the administrative controls and PPE for hearing is indirect measures that are not frequently supervised and hence are overlooked (Efrem et al, 2009).

\section{GENERAL CONVENTIONAL PRINCIPLES OF}

\section{REDUCING NOISE}

A measure to reduce noise includes:

- Maintenance by adjustment, repair or replacement of bad machine parts or lubricating them.

- Substitution by application of less noisy components and materials.
- Change of work process and procedures by select slowest the most appropriate machines or apparatus for a task (Noise Impact Study, 2005).

\section{CONTROL OF NOISE PROPAGATION}

(i)

\section{BARRIERS AND SOUND-ABSORBING MATERIALS}

A barrier is a solid an impervious hindrance to sound which interrupts its straight flow from the source of sound to the receiver. To hinder sound with results, the barrier should be:

- positioned nearest to either the source or receiver;

- $\quad$ structured very high and broad to averagely cover the path of the source-receiver;

- Composed of components that is air-sealed and concrete.

Mid and high frequency sounds that prevails in the noise exposure of a worker, do not penetrate or circumvent barriers as possible as low frequency sounds does. Adding mass entities to a barrier advances its capacity to hinder noise. Multiple layers materials sliced with foam in-between does better by checking the vibration of one layer from another (Efrem, et al 2009).

\section{(ii) ACOUSTIC BARRIERS}

These involve positioning barriers between the source of noise and the receiver in order to reduce the direct impact on the receiver.

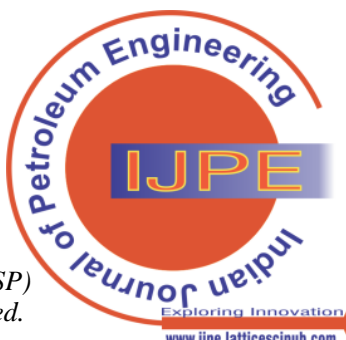




\section{Effects of Noise and Control in Mine Operation}

Examples include sound absorbers, acoustic diffusers, acoustic partition panels (wooden, glass, plastics).

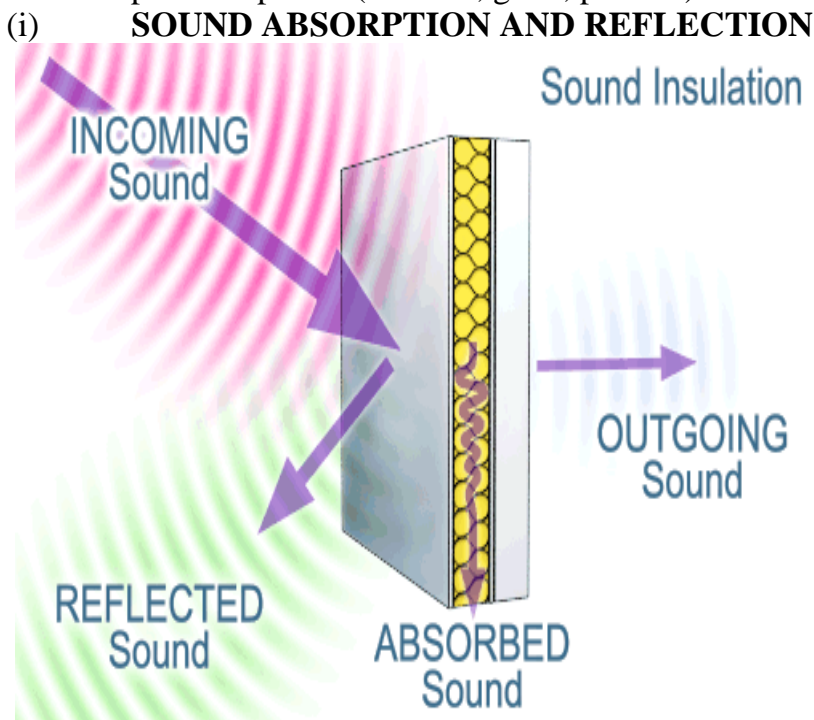

Figure 7: Adsorption of Sound (hushcitysp.com)

This involves absorption of sound by changing acoustic energy into heat energy when sound wave experiences a blockage that is pointed to cellular and sound absorbing structure (less-dense, porous and fibrous materials whose interstices are effectively connected). The degree of the absorption of sound materials is a function of its: (a) resistance to flow; (b) thickness; (c) construction; and (d) frequency of the sound incidence.

Mounting air space between installed sound absorption material and the surface behind it enhances the sound absorption capacity of the installed material. Furthermore, the maximum sound absorption capacity of material happens when its thickness is exactly one-fourth of the wavelength of the considered frequency, i.e.
Thickness
$(\mathrm{t})$
$=1 / 4$
$\mathrm{x} \quad$ wavelength

Equation 1 displays some cases to be unrealistic to mount material with the peak thickness that can absorb sounds of low frequencies. For instance, it is an approximate value of 7 inches peak thickness materials that is best for noise frequency of $500 \mathrm{~Hz}$ and 3.5 inches for $1 \mathrm{KHz}$.

Understanding the noise frequency value empowers one to choose a material of sound-absorption capable of matching such frequencies to its noise energy peak (Efrem et al, 2009).

\section{(ii) THE FUTURE OF NOISE CONTROL INNOVATION}

So many mines have identified the challenges of noise and have embarked on the best available practice and conservation programs. Noise exposures above the range of $100 \mathrm{dBs}$ are connected to equipments and plants such as the pneumatic and percussion tools; the long-wall shearers; the loaders; the chain conveyors and the fans (Rigard, 2018). The future of for noise suppression is the modern ergonomics glasses industrial revolution. onventional compressor packages, making the engines quieter, or possibly to eliminate some of the noise sources altogether. The global awareness levels are much higher and a new generation of acousticians will bring new ideas and technology to industry. It has propensity of a improved

acoustics which can prevent sound emission and provide a better package for absorption.

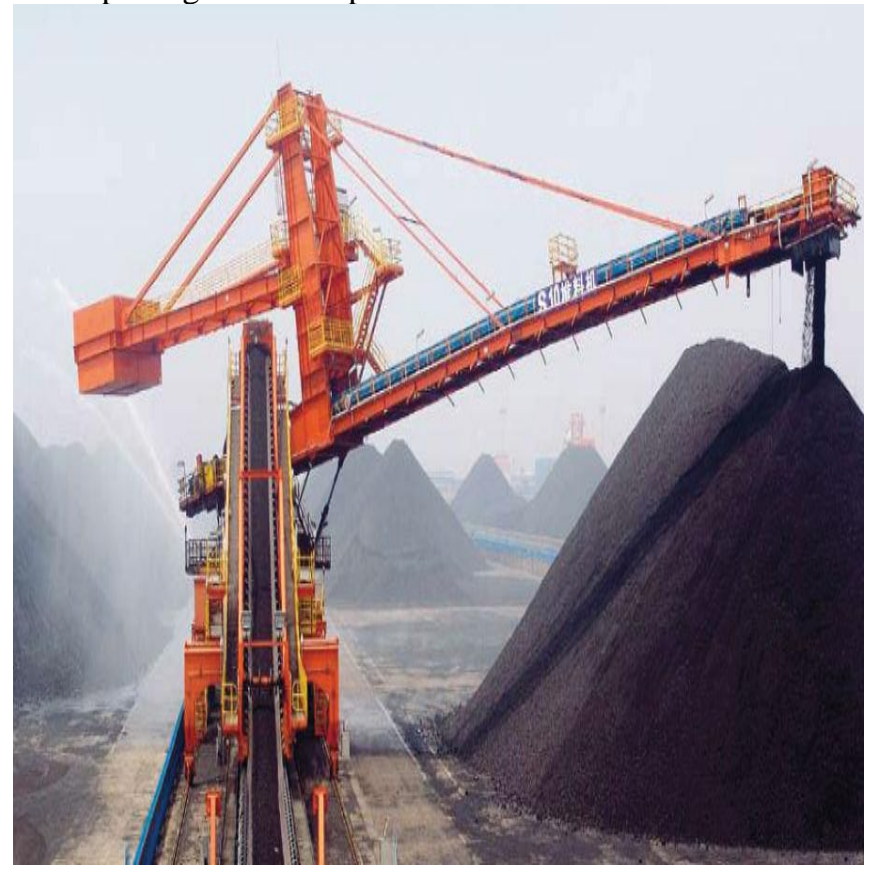

Figure 8: Chain Conveyor (directindustry.com)

\section{EFFECTS OF NOISE ON HUMAN HEALTH}

The impact of noise effect is a function of the duration that one gets exposed to sound.

\section{(i) TEMPORARY THRESHOLD SHIFT (TTS)}

This is a hearing loss for a short time which occurs as a result of being exposed to noisy tasks. It takes about one or two hours that one can start to recover from it when evacuated from such exposure. Absolute recovery from a TTS happens for about 14hours.

\section{(ii) PERMANENT THRESHOLD SHIFT (PTS)}

This is a hearing loss or deafness for a long time which occurs with chances of not healing from it, medically.

\section{HEARING LOSS PROBLEMS}

(a) TINNITUS: is a ringing sound emanating in the ears which is very clear in quiet periods, especially during sleep. This is mostly caused by the permanent threshold shift.

(b) NON-AUDITORY EFFECTS: This is the effect of noise causing stress, nervousness, high heart-beat rate, unnecessary worries, increased pressure of the blood and other blood illnesses.

(c) PRESBYCUSIS: is a hearing loss challenge caused by old-age which commences from age 50 . Presbycusis can be inherited genetically and may be catalysed by the exposure to noise (Cikan, 2014).

\section{EFFECTIVE NOISE MANAGEMENT PLAN}

It is advised that a proper file and audit management plan for hazard is founded in order to place a limit to noise exposure of in the mine. These should include:

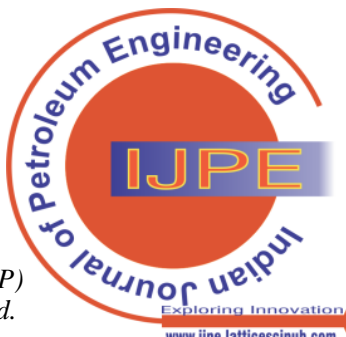


- $\quad$ spell out all only necessary mine operations.

- due adherence to Safety and Health Management policy in the mine.

- official connect with the aims and objectives of Safety and Health Management System

- adequate consultation with the practices and procedures of mine workers and the management.

The reason for the Management Plan is to integrate information about the risks which identifies, analyses, assesses and files hazards of the Safety and Health Management System in the mines. Mine operators are expected to audit and review the effectiveness of Safety and Health Management System of noise to an acceptable degree in the mine for mineral-sizing within the range of 100 to 105 dB (A) (Dennis and Leonard, 1981).

\section{Audiometry}

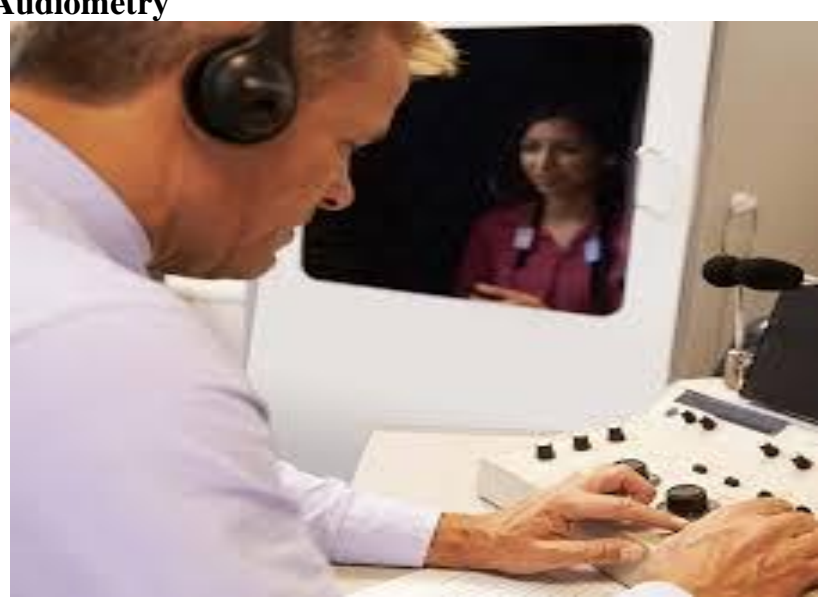

Figure 9: Audiometric Testing

(hearingcompany.com.au)

Audiommetric testing is essential to discover Noise-induced hearing loss (NIHL) especially at this stage of conducting it at baseline appropriately, considering environmental factors (Standards Australia/Standards New Zealand, 1999).

\section{LITERATURE REVIEW}

Rathe (1977) has displayed that for a dipole line origin, such attenuation is $6 \mathrm{~dB}$ that doubles

with the distance near the source. Wilson (1989) and Newton (1687) presumed that generation of sound in air is an constant-temperature process. Later, Laplace and Poisson presumed the process as variable-temperature. Ellison et al (1969) discussed the prodedures of radiated-noise measurement generated by an electric machine. Hassal and

Zaveri (1979) fully explained the generated measurement methods of sound in free field locations. Numerous research scholars have made innovative findings in the scope of noise measurement (Land, 1973; Schultz, 1986; Holmer, 1977 and Hubner, 1977).

National Institute for Occupational Safety and Health (NIOSH, 2003) has suggested that it is widespread to experience and encounter noise overexposure which may cause critical risks of health in the mining sector. It further projected that about 80 percent of mine workers still expose themselves to time-weighted average (TWA) that surpasses $85 \mathrm{~dB}$ and about 25 percent of these category exposes themselves to TWA noise level that surpasses $90 \mathrm{~dB}$.

Noise-induced hearing loss (NIHL) may therefore be inevitable; the of which early detection through audiometric standards helps. The early symptom of NIHL is a little contour (notch) in the audiogram at frequency of about 4 $\mathrm{kHz}$ that deep in and broadens as the exposure to noise intensifies (Taylor et al, 1965; Burns, 1968). Recently also, NIOSH analyzed some audiogram test sample (Franks, 1996) which verifies that at a particular age range, about 50 to 90 percent of miners of coal and about 49 percent of miners of metallic and non-metallic minerals had a hearing loss or damage.

\section{MATERIAL AND METHODS}

This study targets the mechanism of noise, its suppression and control. The review method was applied in this paper.

\section{DATA MINING AND METHODOLOGY}

\section{UNDERGROUND MINES}

The major source of noise in underground mines is drills (fig. 1). This is particularly true of the percussive and pneumatic drills which give out their noise degree in extreme measures of about $115 \mathrm{~dB}$ (A). Drills from the rotary type produce minimal noise degree in the range of about 93 to $97 \mathrm{~dB}$ (A). Load-haul-dump machines and Muckers generate noise degree of about 101 and $107 \mathrm{~dB}$ (A). Their exposure per shift is approximately 6 hours. About $98 \mathrm{~dB}$ (A) noise are produced in long-wall mining systems with operating times limit of about 4 hours per shift. It is expected that in the future a proliferation of long-wall mining will arise despite its low level of noise generation (Dennis and Leonard, 1981).

Table 1: Noise Levels of Underground Mining Machineries

\begin{tabular}{|l|l|l|l|}
\hline Operations In The Mine & Level of Noise [in dB (A)] & $\begin{array}{l}\text { Operating Tine of 8 Hours } \\
\text { (Hours Per Shift) }\end{array}$ & Number of People \\
\hline Muckers & 98 & 4 & 70 \\
\hline Drills & 93 & 3 & 8100 \\
\hline Miners/ Loaders & 101 & 6 & 700 \\
\hline Load Haul Dump & 300 & 3 & 4800 \\
\hline Shuttle Cars & 2 & 64000 \\
\hline Long Walls & 116 & 6 & 3500 \\
\hline
\end{tabular}

\section{SURFACE MINES}

As displayed in figure 2, trucks, drag-lines, dozers, scrapers, front-end loaders and graders generates noises which ranges from 93 to $106 \mathrm{~dB}(\mathrm{~A})$ in surface mines with advisable operating limit times of 8 hours or a little more. Approximately 3,000 drills are also used in surface mining.
Noise generated in surface mines drills are far lesser compared to that of underground. This decrease generation is due to the prolonged length between the drill point and the operator and the proximitybetween the noise barriers and the cabs (Dennis and Leonard, 1981). 


\section{Effects of Noise and Control in Mine Operation}

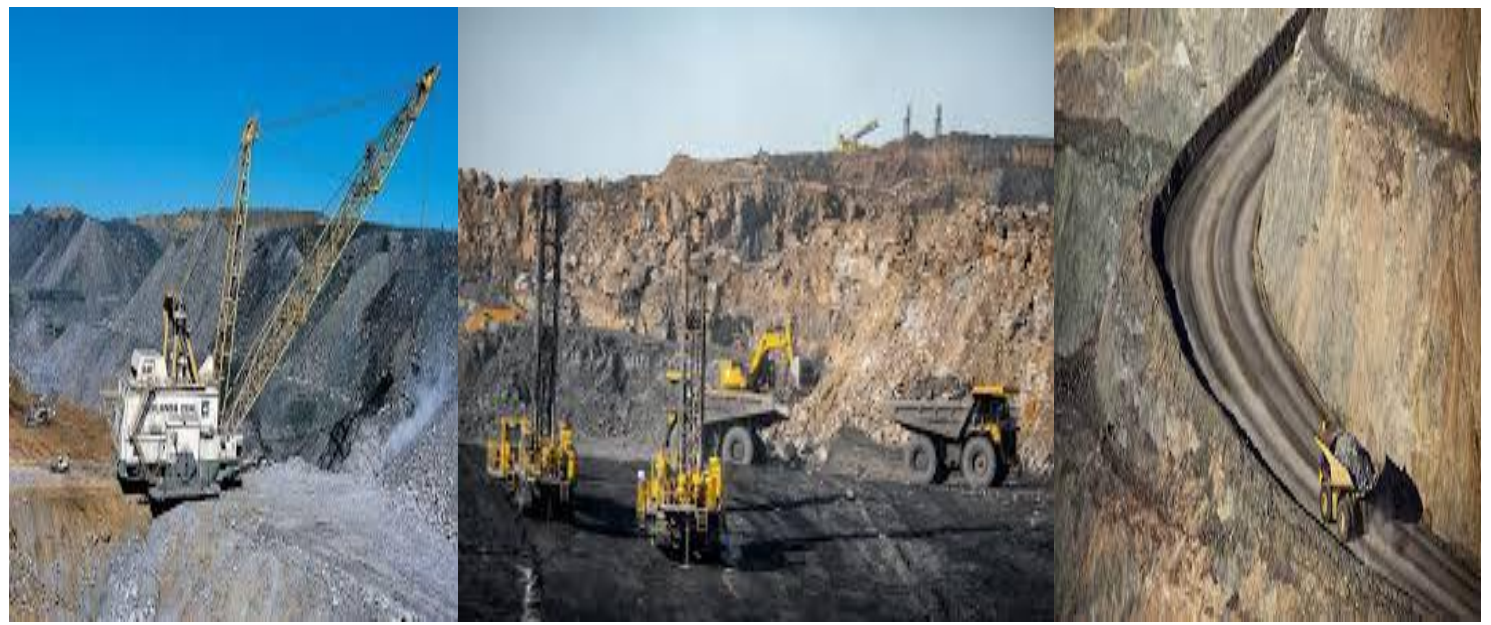

Figure 10: Dragline, Drilling and Blasting and Grader (envlaw.com.au, dreamstime.com and khp.co.za)

Table 2: Noise Levels of Surface Mining Machineries

\begin{tabular}{|l|l|l|l|}
\hline Operations In The Mine & Level of Noise [in dB (A)] & $\begin{array}{l}\text { Operating Tine of 8 Hours } \\
\text { (Hours Per Shift) }\end{array}$ & Number of People \\
\hline Dragline/Shovels & 100 & 8 & 5300 \\
\hline Drills & 93 & 6 & 2700 \\
\hline Front-End Loaders & 102 & 8 & 10200 \\
\hline Dozers & 101 & 8 & 13400 \\
\hline Trucks & 107 & 8 & 10800 \\
\hline Scrapers/Graders & 106 & 8 & 3700 \\
\hline
\end{tabular}

Source: U.S. Bureau of Mines - (Mineral Facts and Problems, 1975).

\section{TREATMENT PANTS}

The Noise levels for the devices used in treatment (crushing, cleaning, processing, and sizing of minerals ores) are within the mean range of about 118 to $122 \mathrm{~dB}(\mathrm{~A})$ with advisable limit of operating time of 3 hours. Crusher in particular which is used in reduction of big sizes of mineral ores generates about 100 to $107 \mathrm{~dB}$ (A). (Dennis and Leonard, 1981).

\section{Data Collection}

Data about effects of noise and control in mine operationwere extracted from the internet. All data was gotten from papers

Data Review and Analysis

Data were analyzed with Microsoft Excel.

Table 4: Health and Safety Hearing for Hearing Level - Executive Classification.

\begin{tabular}{|l|l|l|l|l|}
\hline Age (in Years) & \multicolumn{2}{|c|}{$\mathbf{0 . 5 , 1}$ and 2kHz } & & \multicolumn{2}{|c|}{ 3,4 and 6kHz } \\
\hline & Warning Level & Referral Level & Warning Level & 75 \\
\hline $20-24$ & 45 & 60 & 45 & 87 \\
\hline $25-29$ & 45 & 66 & 45 & 45 \\
\hline $30-34$ & 45 & 72 & 54 & 99 \\
\hline $35-39$ & 48 & 78 & 60 & 111 \\
\hline $40-44$ & 51 & 84 & 66 & 123 \\
\hline $45-49$ & 54 & 90 & 75 & 135 \\
\hline $50-54$ & 57 & 90 & 87 & 144 \\
\hline $55-59$ & 60 & 90 & 100 & 144 \\
\hline $60-64$ & 65 & 90 & 115 & 144 \\
\hline $65+$ & 70 & 90 & 144 \\
\hline
\end{tabular}

Health and Safety Executive (1995).

\section{MSHA NOISE PROBLEM ANALYSIS}

The Mine Safety and Health Administration (MSHA) founded noise exposure constraints for workers in the mine which are stated in the noise rule and regulations of 30 CFR Part 62 that occupational exposure to noise should not surpass 8 hours time-weighted average (TWA) of $90 \mathrm{~dB}$ (A) for any person (This is referred to as PEL i.e. the permissible exposure level), even though higher exposures to noise are allowable for smaller time frame as shown in Table 1 . This noise regulation also applies to the sound received by an individual but not just to sound generated by a equipment or an operational process.

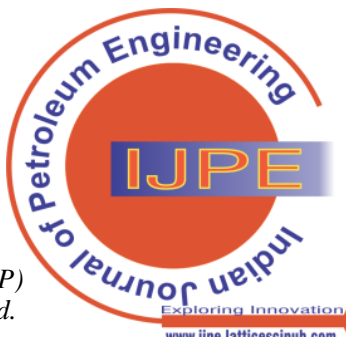


Table 5: Permissible time allowed for a given noise exposure

\begin{tabular}{|c|c|}
\hline DURATION OF EXPOSURE (IN HOURS) & LEVEL OF SOUND [DB(A)] \\
\hline 8 & 90 \\
\hline 6 & 92 \\
\hline 4 & 95 \\
\hline 3 & 97 \\
\hline 2 & 100 \\
\hline 1 & 105 \\
\hline 0.5 & 110 \\
\hline 0.25 & 115 \\
\hline
\end{tabular}

Source: 30 CFR Parts 62

Table 6: The Noise pollution (Regulation and Control) rules, 2000 (Efrem et al, 2009).

\begin{tabular}{|c|c|c|}
\hline \multirow{2}{*}{ Category of Area } & \multicolumn{2}{|c|}{ Limits in dB (A) Leq } \\
\cline { 2 - 3 } & Day Time & Night Time \\
\hline Industrial area & 75 & 55 \\
\hline Commercial area & 65 & 45 \\
\hline Residential area & 55 & 40 \\
\hline Silence zone & 50 & 70 \\
\hline
\end{tabular}

The noise rule stipulates that noise exposures resulting in the MSHA action level (AL) TWA8 of $85 \mathrm{~dB}$ (A) or more require that hearing protection is provided to the exposed miner. Exposures resulting in a TWA8 of $105 \mathrm{~dB}$ (A) or more require dual hearing protection. In practice, this usually means that an ear-muff-type hearing protector must be worn over an earplug-type hearing protector. Dual hearing protection is required in addition to the actions required for enforcing the PEL. Further, the noise rule states that no miner can be exposed to sound levels exceeding 115 $\mathrm{dB}$ (A) for any amount of time. Under the MSHA noise rule for the PEL, sound levels below $90 \mathrm{~dB}$ (A) do not contribute to the calculation of partial noise doses. In other words, a miner could be exposed to a sound level of $89 \mathrm{~dB}$ (A) for a full shift and from a regulatory point of view-receive zero noise dose. This does not mean, however, that this individual has zero risk of receiving hearing damage. The NIOSH recommended exposure limit (REL) is a TWA8 of $85 \mathrm{~dB}$ (A). Noise levels exceeding this REL are considered hazardous by NIOSH (Efrem, et al 2009).

EXAMPLES OF MINING NOISE EXPOSURE

LEVELS (Guidance Note for Management of Noise, 2014).

Table 7: Underground Mining

\begin{tabular}{|c|c|c|}
\hline SURFACE MINING & LEVEL OF SOUND dB (A) & $\begin{array}{l}\text { MAXIMUM UNPROTECTED } \\
\text { TIME OF EXPOSURE }\end{array}$ \\
\hline $\begin{array}{l}\text { Shaft sinking } \\
\text { - on stage beside operator with grab working } \\
\text { - on stage only air hydraulic motor working }\end{array}$ & $\begin{array}{l}106 \\
110\end{array}$ & $\begin{array}{l}4 \text { mins } \\
90 \text { secs }\end{array}$ \\
\hline $\begin{array}{l}\text { Longwall mining } \\
\text { - beside operating shearer and chain } \\
\text { conveyor } \\
\text { - beside operating shearer }\end{array}$ & $\begin{array}{l}94 \\
90\end{array}$ & $\begin{array}{c}1 \mathrm{hr} \\
2.5 \mathrm{hrs}\end{array}$ \\
\hline $\begin{array}{l}\text { Roof bolting } \\
\text { - Falcon, roof bolting in operation } \\
\text { - Borer, Joy single boom drill }\end{array}$ & $\begin{array}{c}112 \\
96\end{array}$ & $\begin{array}{l}58 \text { secs } \\
38 \text { mins }\end{array}$ \\
\hline $\begin{array}{l}\text { Underground coal transport } \\
\text { - shuttle car discharge coal onto belt (high rate) } \\
\text { - } \quad \text { at drive-head at junction of conveyors, coal running }\end{array}$ & $\begin{array}{l}93 \\
94\end{array}$ & $\begin{array}{l}80 \mathrm{mins} \\
1 \mathrm{hr}\end{array}$ \\
\hline Crusher & 99 & 19 mins \\
\hline $\begin{array}{l}\text { Underground } \\
\begin{array}{l}\text { - } \\
\text { - jentilation fans }\end{array}\end{array}$ & $\begin{array}{c}0-100 \\
103-106\end{array}$ & $\begin{array}{c}15 \mathrm{mins}-2.5 \mathrm{hrs} \\
8-9 \mathrm{~m}\end{array}$ \\
\hline $\begin{array}{l}\text { Continuous miner } \\
\text { - Joy CM, miner filling, beside operator }\end{array}$ & 94 & $1 \mathrm{hr}$ \\
\hline
\end{tabular}




\section{Effects of Noise and Control in Mine Operation}

Table 8: Surface Mining

\begin{tabular}{|c|c|c|}
\hline OPERATION/TASK & $\begin{array}{l}\text { LEVEL OF SOUND } \\
\text { DB(A) }\end{array}$ & $\begin{array}{l}\text { MAXIMUM UNPROTECTED } \\
\text { TIME OF EXPOSURE }\end{array}$ \\
\hline $\begin{array}{l}\text { Processing plant equipment } \\
\text { - } \quad \text { vacuum pumps } \\
\text { - } \quad \text { chutes and hoppers }\end{array}$ & $\begin{array}{l}96-100 \\
100-108\end{array}$ & $\begin{array}{l}15-38 \text { mins } \\
2-15 \text { mins }\end{array}$ \\
\hline $\begin{array}{l}\text { Coal preparation plant } \\
\text { • } \quad \text { beside crusher mill } \\
\text { • } \quad \text { beside operator of vibrating screens }\end{array}$ & $\begin{array}{l}102 \\
98\end{array}$ & $\begin{array}{l}0 \text { mins } \\
24 \text { mins }\end{array}$ \\
\hline $\begin{array}{cl}\text { Surface mining equipment } \\
\text { - } & \text { Electric shovels } \\
\text { - } & \text { Haul trucks } \\
\text { - } & \text { Grader }\end{array}$ & $\begin{array}{l}75-90 \\
84-109 \\
85-100\end{array}$ & $\begin{array}{l}0-2.5 \text { hrs } \\
9 \text { hrs }-11 \text { secs } \\
8 \text { hrs }-15 \text { mins }\end{array}$ \\
\hline $\begin{array}{l}\text { Earthmoving equipment } \\
\text { - } \quad \text { front end loader } \\
\text { - } \text { dragline engine room }\end{array}$ & $\begin{array}{l}104-108 \\
92-101\end{array}$ & $\begin{array}{l}2-6 \text { mins } \\
12-100 \text { mins }\end{array}$ \\
\hline
\end{tabular}

SOURCE: managing noise in the coal industry to protect hearing, NSW Government (Coal Services, 2010).

Table 9: The relationship between noise level and its exposure time (Safe Work Australia, 2011)

\begin{tabular}{|l|l|}
\hline LEVEL OF NOISE DB(A) & TIME OF EXPOSURE \\
\hline 85 & 8 hours \\
\hline 88 & 4 hours \\
\hline 91 & 2 hours \\
\hline 94 & 1 hour \\
\hline 97 & 30 minutes \\
\hline 100 & 15 minutes \\
\hline 103 & 7.5 minutes \\
\hline 106 & 3.8 minutes \\
\hline 109 & 1.9 minutes \\
\hline 112 & 57 seconds \\
\hline 115 & 28.8 seconds \\
\hline 118 & 14.4 seconds \\
\hline 121 & 7.2 seconds \\
\hline 124 & 3.6 seconds \\
\hline 127 & 1.8 seconds \\
\hline 130 & 0.9 seconds \\
\hline
\end{tabular}

\section{RESULTS AND DISCUSSION}

Table 10:

\section{$0.5,1$ and $2 \mathrm{kHz}$}

\begin{tabular}{|l|l|l|}
\hline \multicolumn{2}{|c|}{$\mathbf{0 . 5}, \mathbf{1}$ and 2kHz } & Referral (Recommended) Level \\
\hline Age in Years & Warning Level & 60 \\
\hline $20-24$ & 45 & 66 \\
\hline $25-29$ & 45 & 72 \\
\hline $30-34$ & 45 & 78 \\
\hline $35-39$ & 48 & 84 \\
\hline $40-44$ & 51 & 90 \\
\hline $45-49$ & 54 & 90 \\
\hline $50-54$ & 57 & 90 \\
\hline $55-59$ & 60 & 90 \\
\hline $60-64$ & 65 & 90 \\
\hline $65+$ & 70 & \\
\hline
\end{tabular}

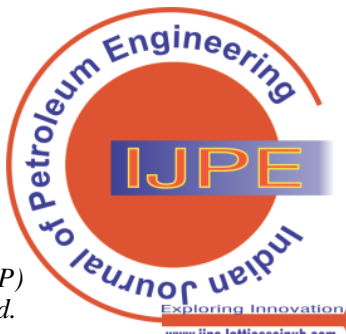




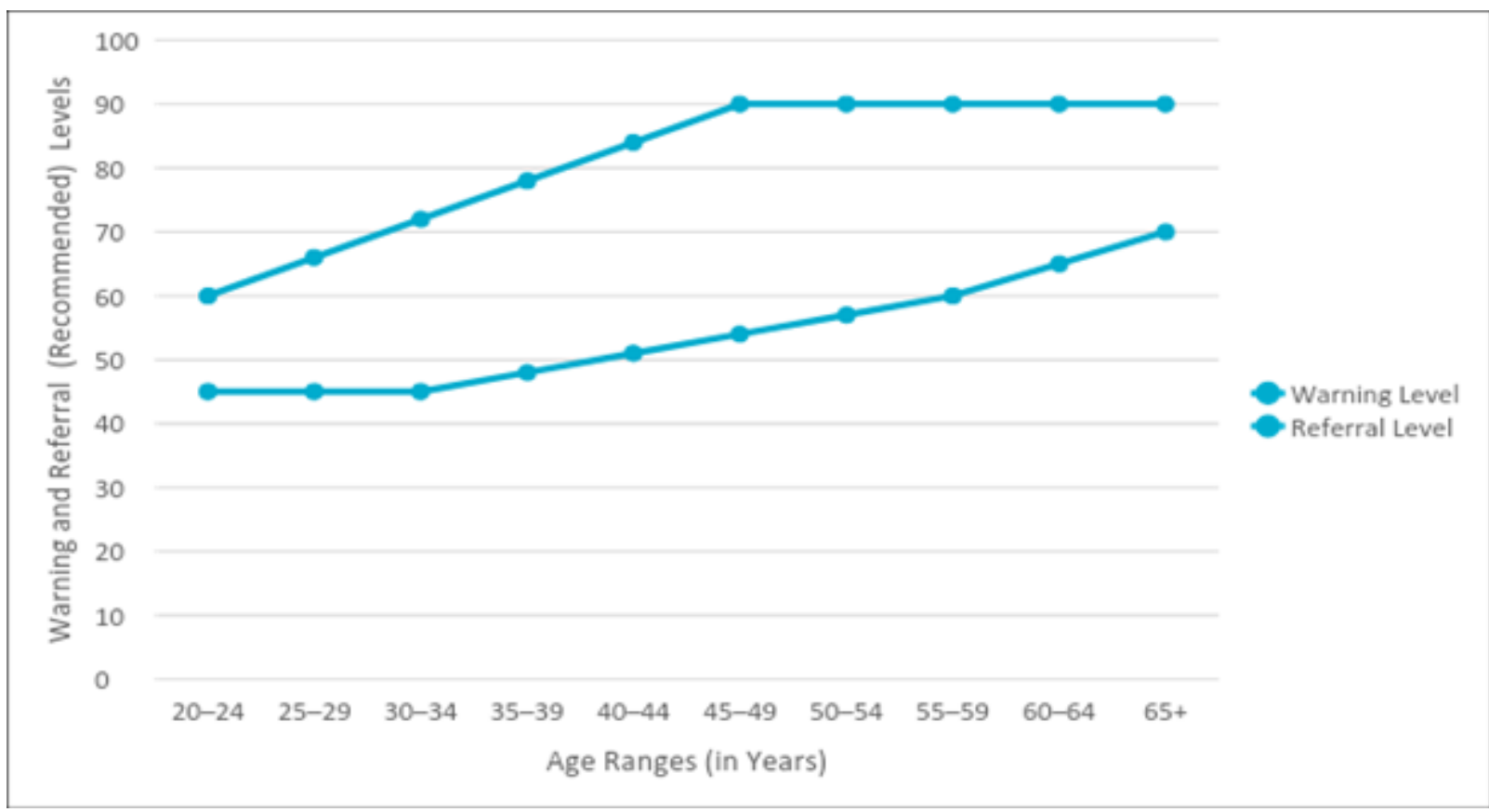

Figure 11: 0.5, 1 and $2 \mathrm{KHz}$ Warning and Referral Levels against Age Ranges

Table 11:

\begin{tabular}{|l|l|l|}
\hline \multicolumn{2}{|c|}{$\mathbf{3 , 4}$ and 6kHz } \\
\hline Age in Years & Warning Level & Referral (Recommended) Level \\
\hline $20-24$ & 45 & 75 \\
\hline $25-29$ & 45 & 87 \\
\hline $30-34$ & 45 & 99 \\
\hline $35-39$ & 54 & 111 \\
\hline $40-44$ & 60 & 123 \\
\hline $45-49$ & 66 & 135 \\
\hline $50-54$ & 75 & 144 \\
\hline $55-59$ & 87 & 144 \\
\hline $60-64$ & 100 & 144 \\
\hline $65+$ & 115 & 144 \\
\hline
\end{tabular}

Table r: Permissible Time allowed for a given noise exposure

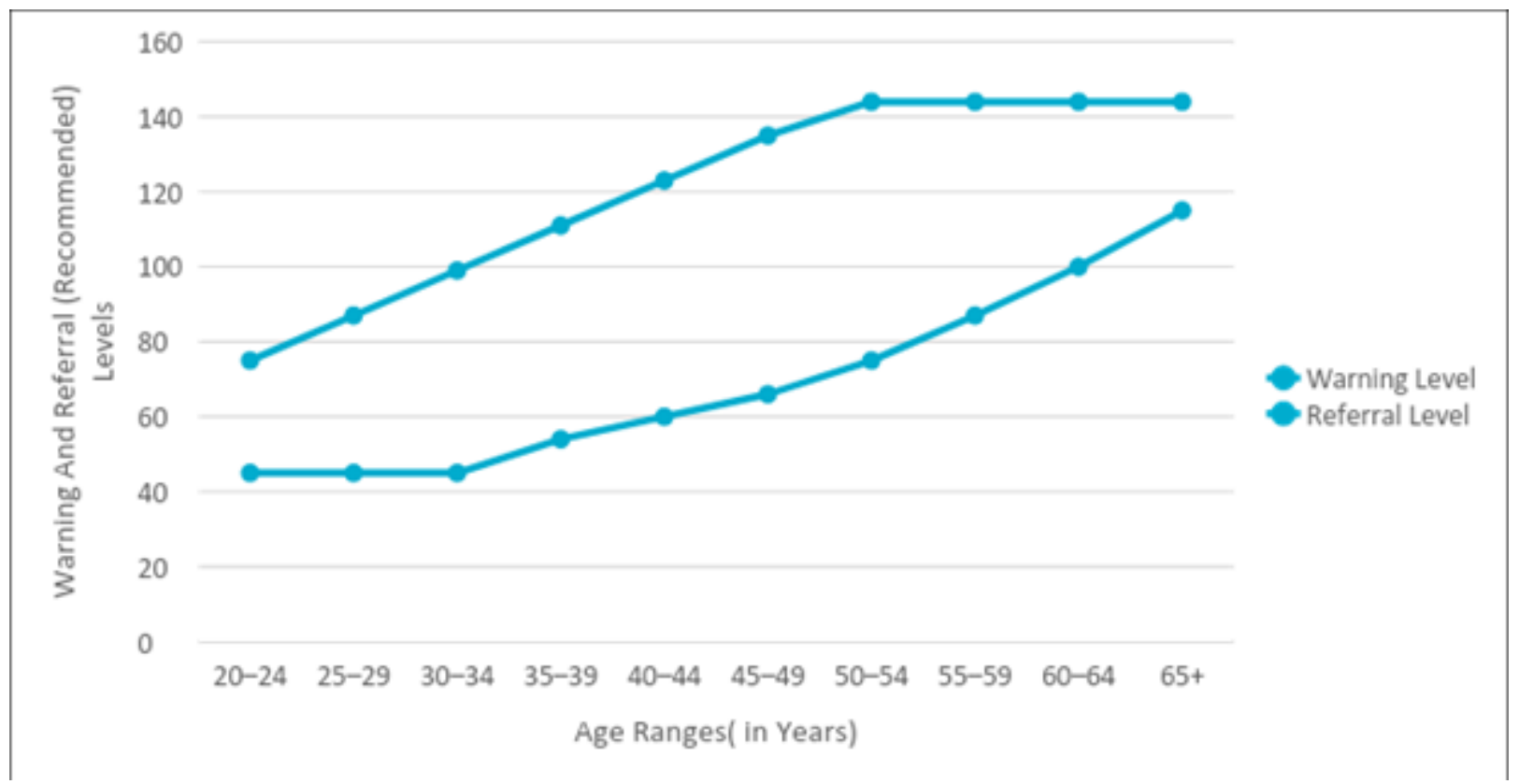

Figure 12:3, 4 And 6kHz Warning and Referral Levels Against Age Ranges

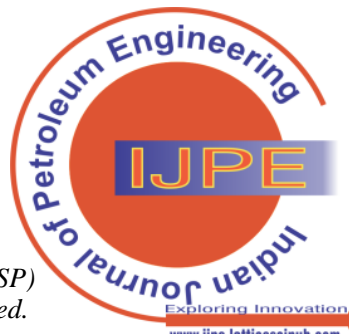




\section{Effects of Noise and Control in Mine Operation}

Table 12:

\begin{tabular}{|l|l|}
\hline DURATION OF EXPOSURE (IN HOURS) & LEVEL OF SOUND dB (A) \\
\hline 8 & 90 \\
\hline 6 & 92 \\
\hline 4 & 95 \\
\hline 3 & 97 \\
\hline 2 & 100 \\
\hline 1 & 105 \\
\hline 0.5 & 110 \\
\hline 0.25 & 115 \\
\hline
\end{tabular}

Source: 30 CFR Part 6

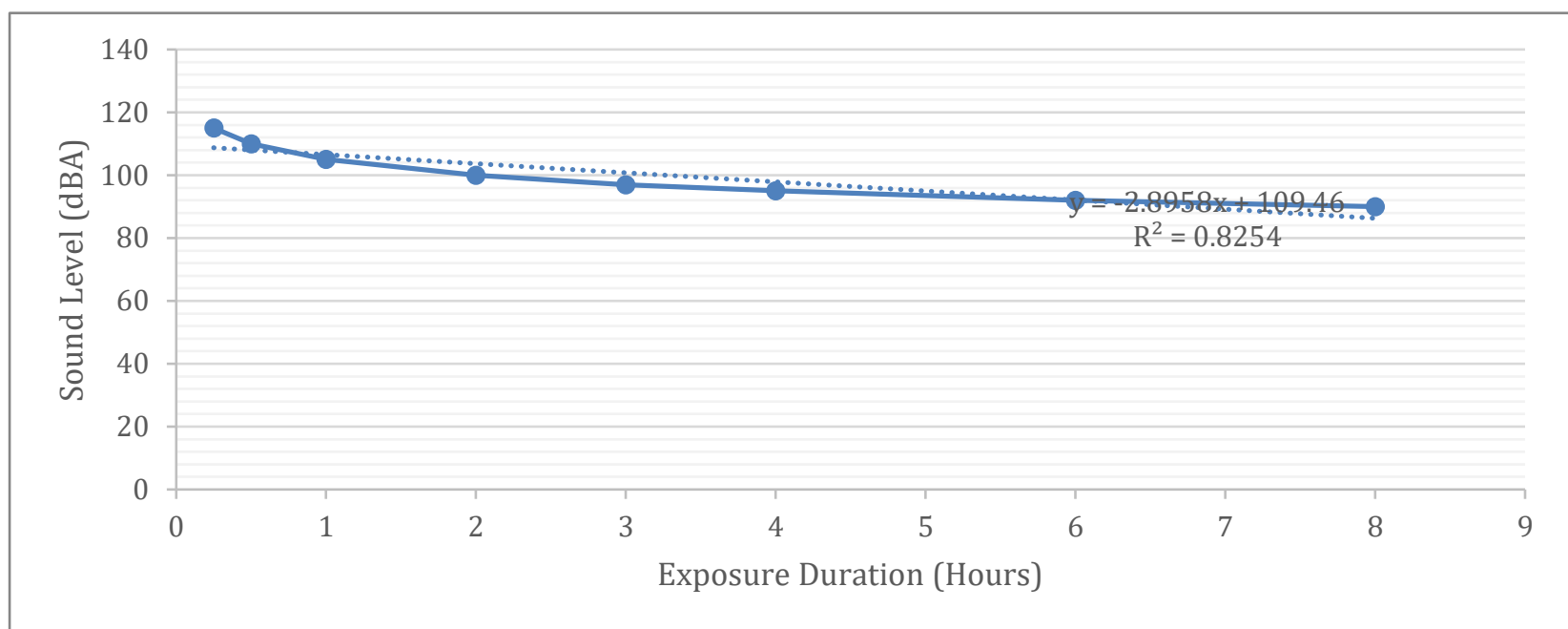

Figure 13: Sound Level against Exposure Duration

Table 13: The Noise pollution (Regulation and Control) rules, 2000 (Efrem et al, 2009).

\begin{tabular}{|l|l|l|}
\hline \multirow{2}{*}{ CATEGORY OF AREA } & \multicolumn{2}{|c|}{ LIMITS IN DB(A) LEQ } \\
\cline { 2 - 3 } & DAY TIME & NIGHT TIME \\
\hline Industrial area & 75 & 70 \\
\hline Commercial area & 65 & 55 \\
\hline Residential area & 55 & 45 \\
\hline Silence zone & 50 & 40 \\
\hline
\end{tabular}

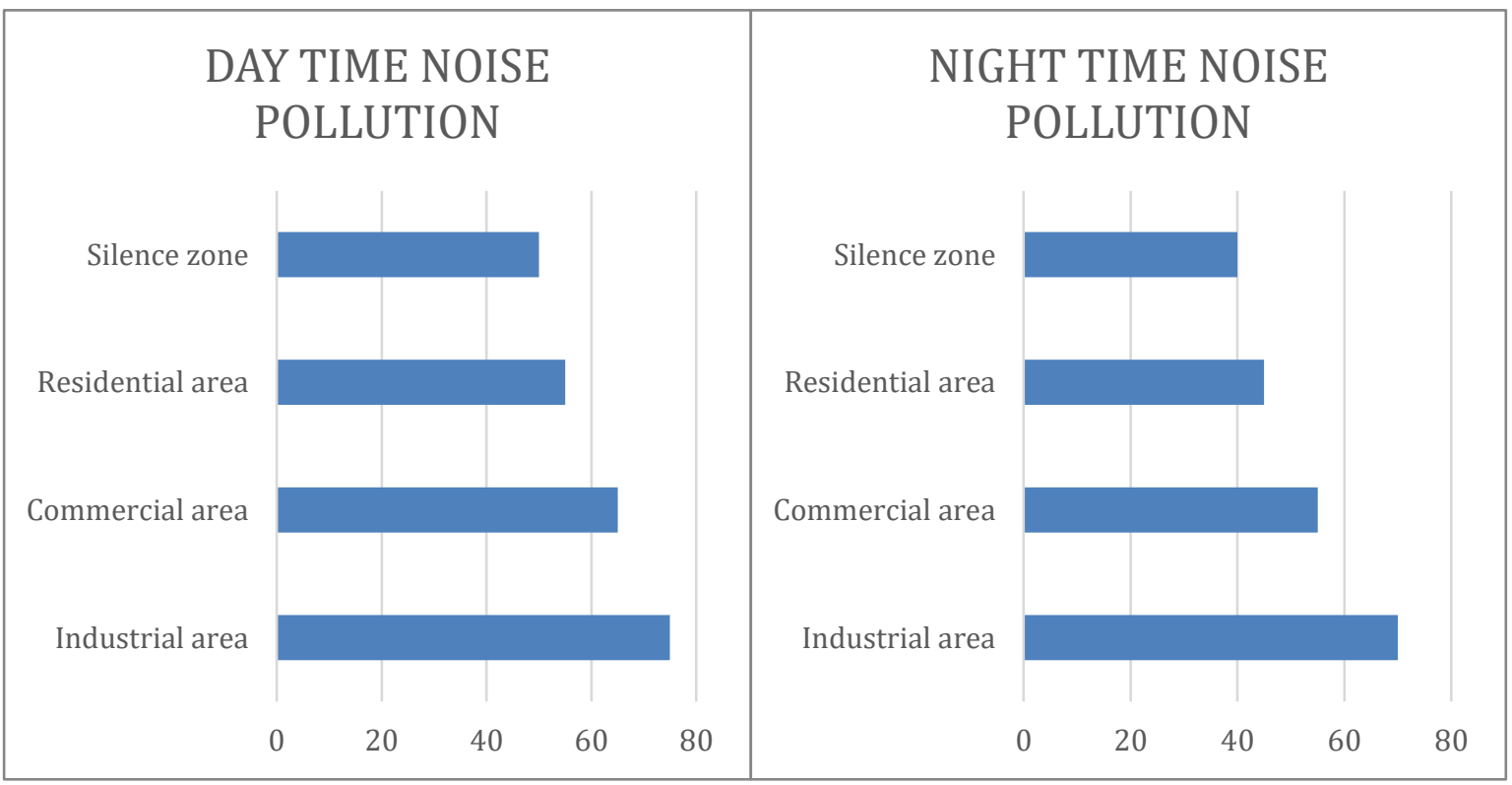

Figure 14: Noise Pollution - Day Time (a) And Night Time (b)

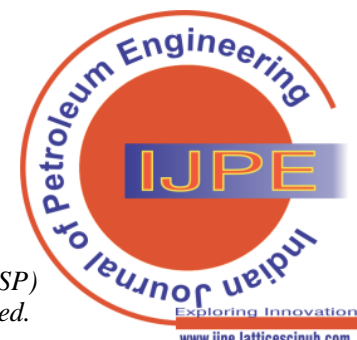


Table 14:

\begin{tabular}{|l|l|l|l|}
\hline MINE OPERATIONS & LEVEL OF NOISE [IN DB (A)] & $\begin{array}{l}\text { OPERATING TINE OF 8 } \\
\text { HOURS (HOURS PER SHIFT) }\end{array}$ & $\begin{array}{l}\text { NUMBER } \\
\text { PEOPLE }\end{array}$ \\
\hline Muckers & 98 & 4 & 70 \\
\hline Drills & 93 & 3 & 8100 \\
\hline Long Walls & 107 & 6 & 3500 \\
\hline Shuttle Cars & 116 & 2 & 64000 \\
\hline Load Haul Dump & 100 & 3 & 4800 \\
\hline Miners/ Loaders & 101 & 6 & 700 \\
\hline
\end{tabular}

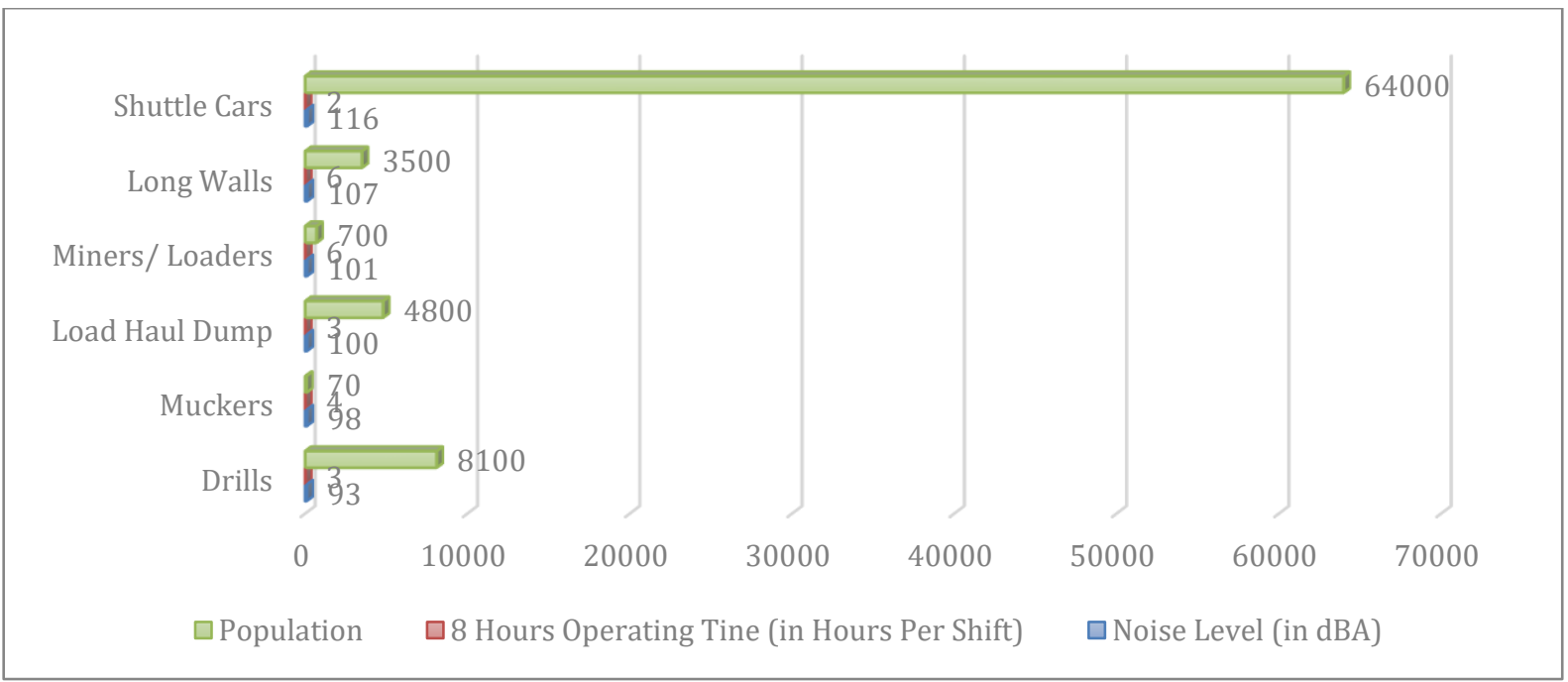

Figure 15: Mine Operations (Underground Machineries)

Table 15:

\begin{tabular}{|l|l|l|l|}
\hline MINE OPERATIONS & LEVEL OF NOISE [IN DB (A)] & $\begin{array}{l}\text { OPERATING TINE OF 8 HOURS } \\
\text { (HOURS PER SHIFT) }\end{array}$ & $\begin{array}{l}\text { NUMBER } \\
\text { PEOPLE }\end{array}$ \\
\hline Dragline/Shovels & 100 & 8 & 5300 \\
\hline Dozers & 101 & 8 & 13400 \\
\hline Drills & 93 & 6 & 2700 \\
\hline Front-End Loaders & 102 & 8 & 10200 \\
\hline & & & \\
\hline Trucks & 107 & 8 & 10800 \\
\hline Scrapers/Graders & 106 & 8 & 3700 \\
\hline
\end{tabular}

\section{MINE OPERATIONS (SURFACE MACHINERIES)}

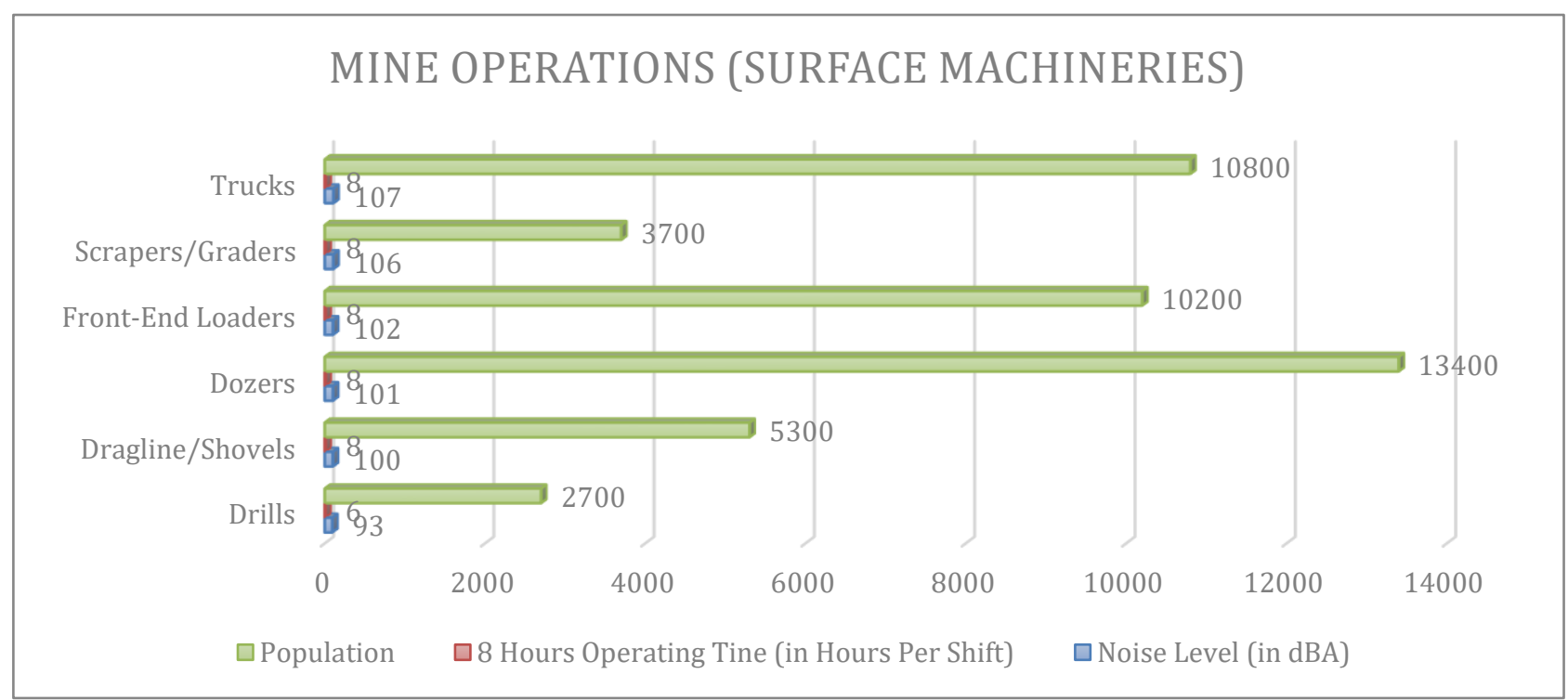

Figure 16: Mine Operations (Surface Machineries)

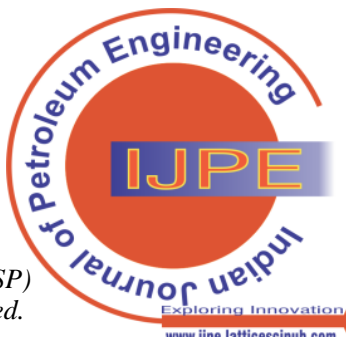


Effects of Noise and Control in Mine Operation

Table 16:

\begin{tabular}{|l|l|l|l|}
\hline MINE OPERATIONS & LEVEL OF NOISE [IN DB (A)] & $\begin{array}{l}\text { OPERATING TINE OF 8 HOURS } \\
\text { (HOURS PER SHIFT) }\end{array}$ & $\begin{array}{l}\text { NUMBER } \\
\text { PEOPLE }\end{array}$ \\
\hline Screens & 100 & 8 & 42000 \\
\hline Crushers & 100 & 8 & 2500 \\
\hline Shake - outs & 90 & 8 & 800 \\
\hline Rod/Ball Mills & 107 & 8 & 20000 \\
\hline Kilns & 118 & 3 & 800 \\
\hline Chutes & 105 & 8 & 29000 \\
\hline
\end{tabular}

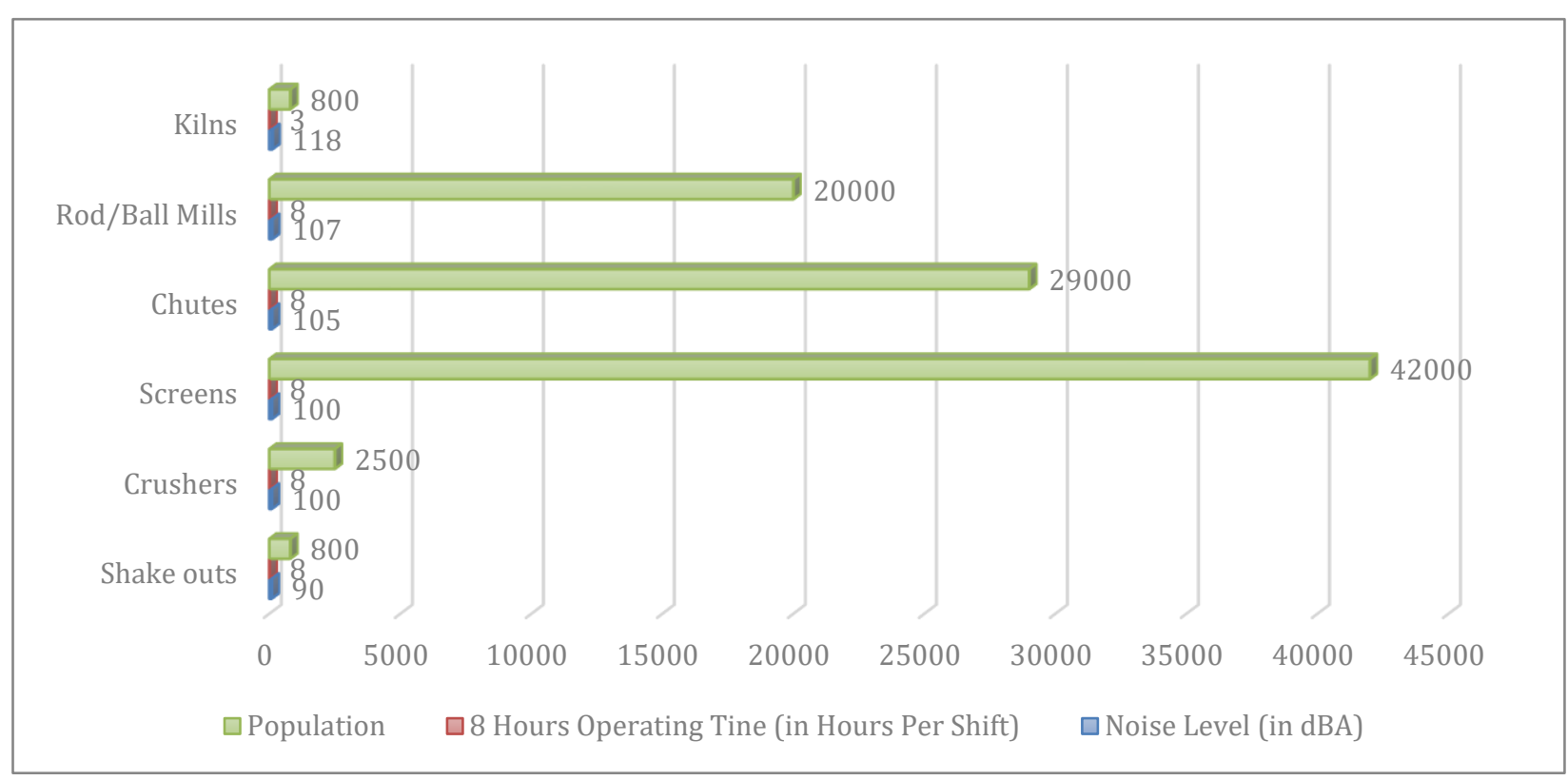

Figure 17: Mine Operations (Treatment Plants)

Table 17:

\begin{tabular}{|l|l|l|}
\hline MINING OPERATIONS & $\begin{array}{l}\text { EQUIVALENT LEVEL OF NOISE [DB } \\
\text { (A)] }\end{array}$ & DISCOMFORT DEGREE (0-5) \\
\hline Plant Treatment & & \\
\hline Band Facilities & 75.3 & 2 \\
\hline Sieve Systems & 88.8 & 4 \\
\hline Jaw crushers & 90.6 & 4 \\
\hline Tertiary Crushers & 89.4 & 4 \\
\hline
\end{tabular}

(Safe Work Australia, 2011)

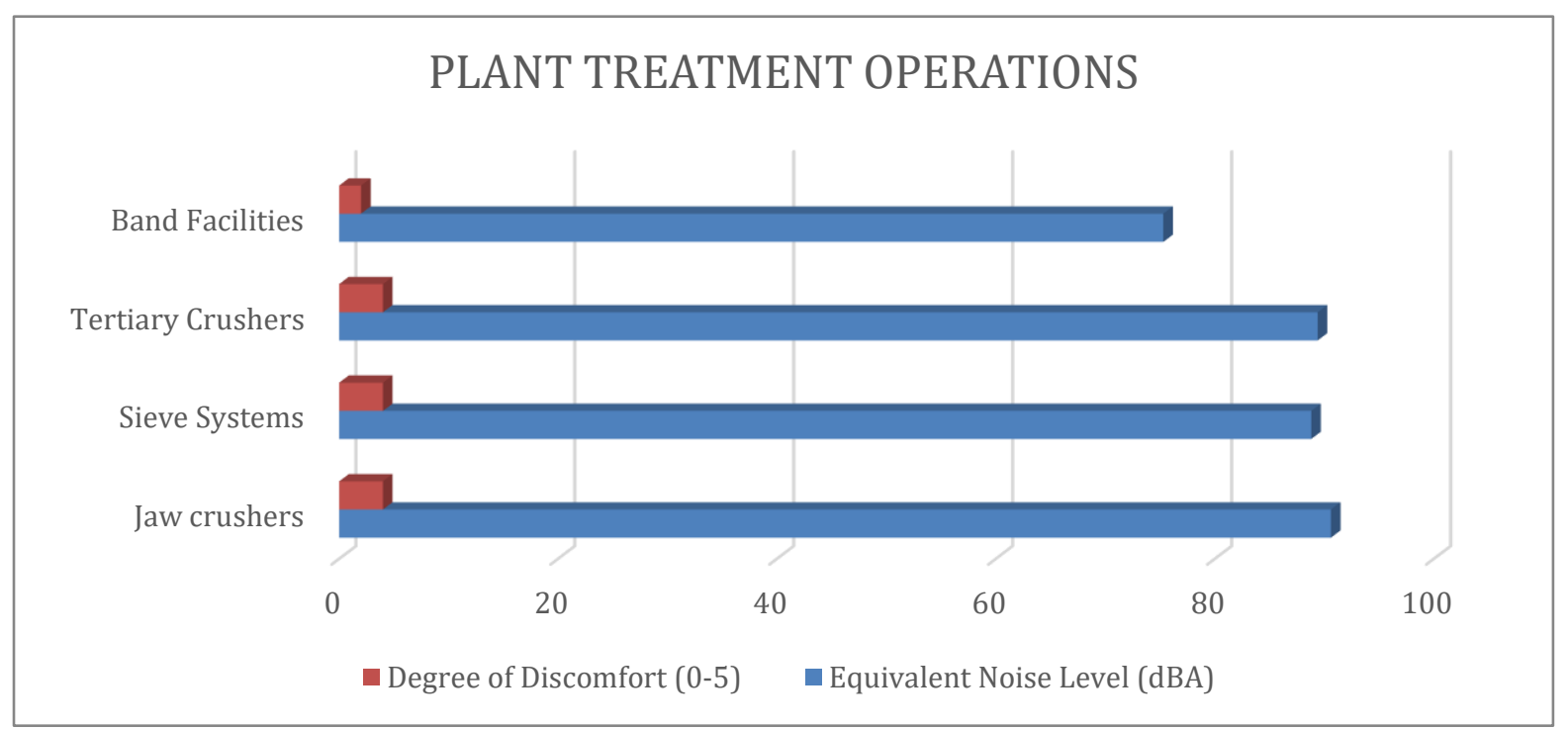

Figure 18: Plant Treatment Operations

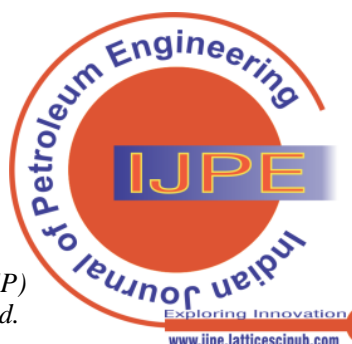


Table 18:

\begin{tabular}{|l|l|l|}
\hline MINING OPERATIONS & $\begin{array}{l}\text { EQUIVALENT LEVEL OF NOISE [DB } \\
\text { (A)] }\end{array}$ & DISCOMFORT DEGREE (0-5) \\
\hline \multicolumn{2}{|c|}{ Quarry } \\
\hline Trucks (FORD) & 72.6 & 0 \\
\hline Graders & 72.6 & 2 \\
\hline Excavators & 73.6 & 1 \\
\hline Bulldozers & 91.5 & 4 \\
\hline Hydraulic Hammers & 85.1 & 3 \\
\hline
\end{tabular}

(Safe Work Australia, 2011).

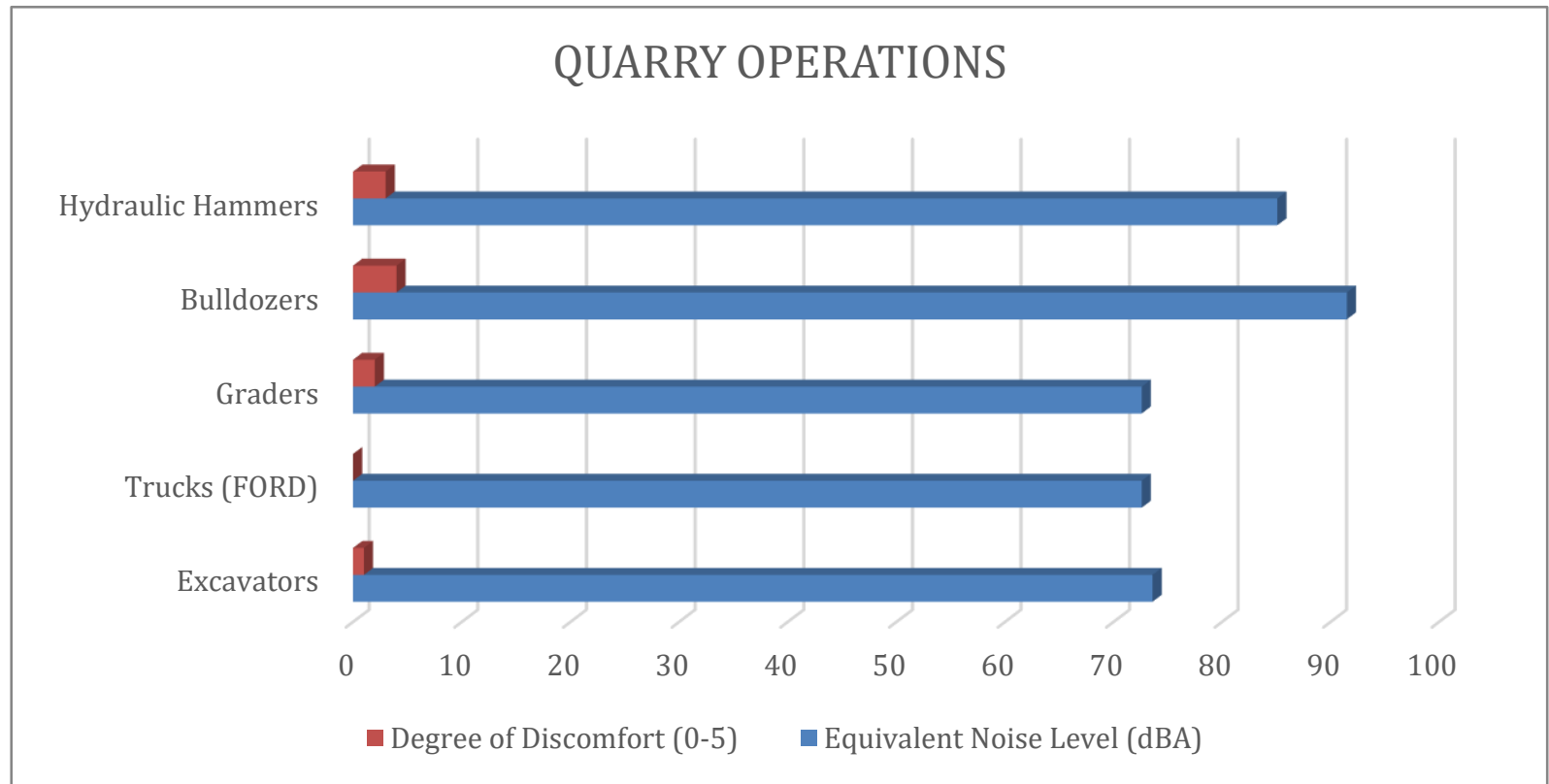

Figure 19: Quarry Operations

Table 19:

\begin{tabular}{|c|c|c|c|c|c|c|c|c|c|c|c|c|c|c|c|c|}
\hline $\begin{array}{l}\text { LEVEL OF } \\
\text { NOISE DB(A) }\end{array}$ & 85 & 88 & 91 & 94 & 97 & 100 & 103 & 106 & 109 & 112 & 115 & 118 & 121 & 124 & 127 & 130 \\
\hline $\begin{array}{l}\text { TIME OF } \\
\text { EXPOSURE } \\
\text { (IN SECONDS) }\end{array}$ & 28800 & 14400 & 7200 & 3600 & 1800 & 900 & 450 & 228 & 114 & 57 & 29 & 14 & 7.2 & 3.6 & 1.8 & 0.9 \\
\hline
\end{tabular}

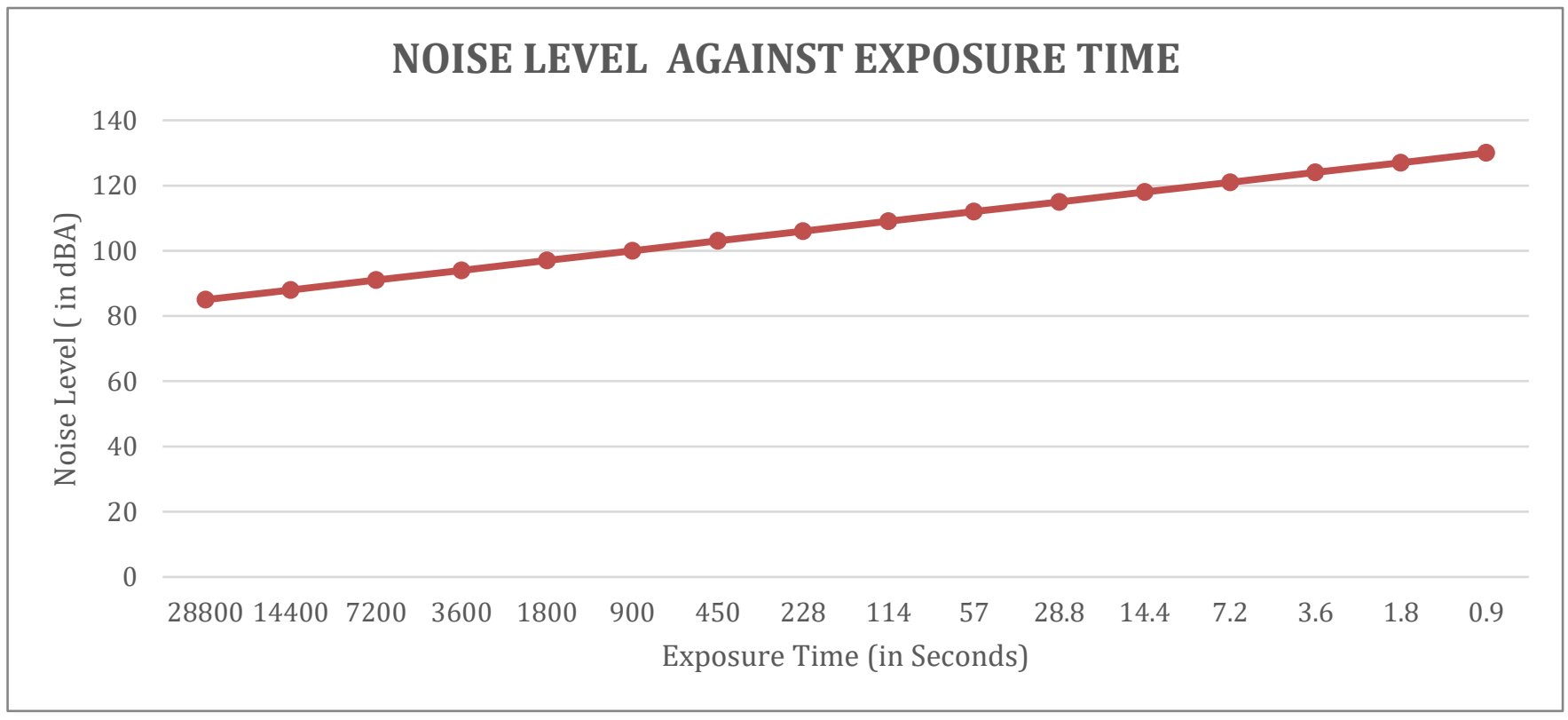

Figure 20: Noise Level against Exposure Time

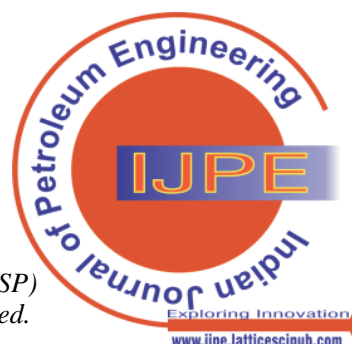




\section{Effects of Noise and Control in Mine Operation}

In Figure 11, the differing frequencies of range $(0.5-2)$ $\mathrm{KHz}$ were considered for warning and recommended levels. Mine workers within the age bracket of $20-44$ years have an average recommended threshold of about $72 \mathrm{KHz}$ while ages 45 - 65 and beyond maintains threshold frequency of $90 \mathrm{KHz}$. In Figure 12, the range of $3-6 \mathrm{KHz}$ were considered for warning and recommended levels.

The workers with the bracket of 20 - 49 years have an average recommended threshold frequency of $105 \mathrm{KHz}$, while ages 50 - 65 and beyond maintains threshold frequency of $144 \mathrm{KHz}$. In Figure13, sound level against exposure duration was considered. The maximum of $90 \mathrm{~dB}$ (A) matched with the normal 8hours exposure of a worker to noise while $115 \mathrm{~dB}(\mathrm{~A})$ maximum with exposure of 15 minutes (0.25 hours). In Figure 14 (a) and (b), noise pollution for day and night time were considered, for residential and working locations, and their limits. During the daytime, the maximum limit of noise was highest in industrial area, and the least was the silence zone. At the night-time, the same trend with different values was observed.

In Figure 15, Mine operation machineries in underground mine were considered For a 8 hours operating time, the operation with the most noise level is Shuttle Cars with 116 $\mathrm{dB}(\mathrm{A})$, while the least is Drills with 93dB (A); Loaders and Load Dumps are on the average of $100.5 \mathrm{~dB}$ (A). In Figure 16. Mine operation machineries in surface mine was considered. For an 8 hours operating time, the operation with the highest noise level are Trucks with $107 \mathrm{~dB}$ (A), while the least are Drills with 93dB (A); Dozers and Frontend Loaders are on the average with 101.5bB (A). In Figure 17, Mine operation machineries in surface mine was considered. For an 8 hours operating time, the operation with the highest noise level are Kilns with $118 \mathrm{~dB}(\mathrm{~A})$, while the least are Shake-outs with $90 \mathrm{~dB}$ (A); Crushers, Screens and Chutes are on the average with 102.5bB (A). In Figure 18, a plant treatment operation in a location in Australia was considered. The machineries that contributed to the most noise is the Jaw Crusher with $90.6 \mathrm{~dB}$ (A), having a discomfort degree of 4 out of 5 scale. The Band Facilities made the least noise of $75.3 \mathrm{~dB}$ (A) having a discomfort degree of 2 against 5 scale. In Figure 19, quarry operation machineries and their discomfort degree levels were considered. The machinery that contributed the lowest noise was the excavator with $73.6 \mathrm{~dB}$ (A) having discomfort level of 1 against 5. Bulldozers made the highest noise of $91.5 \mathrm{~dB}$ (A) having a discomfort degree of 4 out of 5 scale. In Figure 20, noise level against exposure time was considered. The maximum noise level permitted is $85 \mathrm{~dB}(\mathrm{~A})$ for 2800 seconds (8- hours) exposure of time, while the minimum noise level permitted is $130 \mathrm{~dB}(\mathrm{~A})$ for 0,9 seconds $(0.00025$ Hours) exposure of time.

\section{CONCLUSION AND RECOMMENDATION}

Mining works produce so much noise and sounds that are detrimental to hearing, man's health and the workplace. Calculations can be done to ascertain noise and pressure level ranges in order to indicate how to avoid exposures to fit them. Frequency analysis has been made to guide for proper selection of appropriate engineering control methods. Noise could also be reduced by proper maintenance, substitutions of less noisy materials, change of work methods, use of barriers for enclosures for equipment, reverberation controls, and so on.

\section{REFERENCE}

1. Burns W. and John M.(1968).

2. Cikan P.(2013): Noise Survey and Noise Modelling Of Open Cast Machineries in Mines; A Thesis Submitted In Partial fulfilment Of the Requirements for the Degree of Bachelor of Technology in Mining Engineering, Department of Mining Engineering, National Institute of Technology, Rourkela.

3. Cinar I. and Sensogut C. (2013): Evaluation of Noise Measurements Performed in Mining Sites for Environmental Aspects; Int. J. Environ. Res., 7(2):383-386.

4. Dennis A. G. and Leonard C.M. (1981): Noise in The Mining Industry - An Overview; U.S. Department of Labor; MSHA/1 R1129.

5. Efrem R. R., Robert F.R., David S. Y., and Shawn J. P. (2009): Noise Control in Underground Metal Mining; Department Of Health And Human Services - Centres for Disease Control and Prevention National Institute for Occupational Safety and Health (NIOSH)IC 9518 - Information circular, 2009.

6. Ellison A. J., Moore C. J. and Yang S. J. (1969): Methods of Measurement of Acoustic Noise Radiated by an Electric Machines, Proc. lEE, No 116, pp. 1419-143 1. [CrossRef]

7. Franks J.R. (1996): Analysis of Audiograms for a Large Cohort of Noise-exposed Miners, Cincinnati, US Department of Health and Human Services, Public Health Service, Centers for Disease Control and Prevention, National Institute for Occupational Safety and Health, Division of Biomedical and Behavior Sciences.

8. Guidance Note (2004): for Management of Noise in Mines; Mining and Quarrying Safety and Health - Coal Mining Safety and Health Act, Department of Natural resources ( Mines And Energy), Version 1.

9. Hassal J. R. and Zaveri K. (1979): Acoustic Noise Measurement.

10. Health and Safety Executive (1995): A Guide to Audiometric Testing Programmes; Guidance Notes No. MS26, London - Her Majesty's Stationery Office.

11. Holmer C. I. (1977): Investigation for Procedures for Estimation of Sound Power in the Free Field - Above a Reflecting Plane, J. Acoust. Soc. Am., Vol. 61, No 2. [CrossRef]

12. Hubner G. (1977): Qualification Procedures for Free Field Conditions for Sound Power Determination of the Appropriate Environmental Correction, J. Acoust. Soc.Am., Vol. 61, No 2. [CrossRef]

13. Land W. W. (1973): Noise Measurements Standards for Machinery in Situ, J. Acoust. Soc. Am., Vol. 54, No 4

14. Newton, I. (1687): Philosophiae Naturalis Principia Mathematica, London. [CrossRef]

15. NIOSH (2003): Hearing Loss Prevention Highlights; http://www.cdc.gov/niosh/

mining/highlights/hearing_loss_prevention_highlights.htm.

16. Noise Impact Study (2005): Sand \& Gravel Mining and Accessory Uses. Empire Township, Dakota County, Minneapolis, MN 554151199.

17. Rathe E. (1977): Railway Noise Propagation, J. of Sound. and Vibration, Vol. 51, pp.371388. [CrossRef]

18. Rigard J.S.(2008): The Exploration of Modern Noise Control Measures for Mining Operations. Proceedings of the Internationa Conference on Industrial Engineering and Operations Management, Department of Operations Management University of South Africa, Pretoria / Johannesburg, South Africa.

19. Safe Work Australia (2011): Managing Noise and Preventing Hearing Loss at Work, Code of Practice, Safe Work Australia, ACT.

20. Schultz, T. J. (1986): Outlook for the In-Situ Measurement of Noise from Machines, J. Acoust. Soc. Am., Vol. 54, No. 4. [CrossRef]

21. Standards Australia/Standards New Zealand (1998): Occupational Noise Management Part 4 - Auditory Assessment; No. AS/NZS 1269.4, 31, Hombush/Wellington.

22. Wilson C. E.(1989): Noise Control, Harper and Row, New York, pp 10.

23. Taylor et al (1965): Study of noise and hearing in jute weaving ;38:113-120. [CrossRef] 


\section{AUTHORS PROFILE}

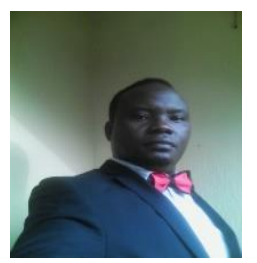

Mining Engineer Amosu cyril olumuyiwa Professional background:

- $\quad$ Lecturer and researcher at Yaba College of Technology, Lagos, Nigeria. ।

- Associate Environmental Professionals (AEP), National registry Of Environmental

- Professionals (NREP). Education:

- $\quad$ Master of Engineering (M. Eng.) in Mining Engineering from Federal University of Technology Akure, Nigeria (2019 - Date).

- Masters (M. Sc.) in Petroleum Engineering and Project Development (2004 - 2005).

- $\quad$ Bachelors of Engineering (B. Eng.) in Mining Engineering from Federal University of Technology Akure, Nigeria (1995 2001).

Previous publishing experience

About ten (10) journals published already with different publishers which can be found on Google Scholar, ResearchGate, Publon and Orcid. These journals captures Mining and Petroleum.

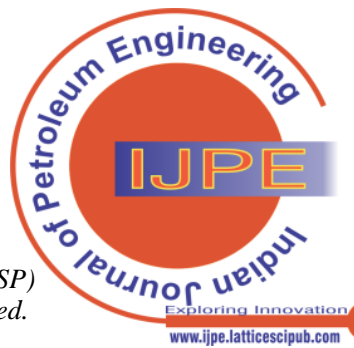

